\title{
$\boldsymbol{E}$

2013, Vol. 1, No. 1

\section{Opportunities for Doing Business with Countries Neighbouring V4 - The Case of Ukraine}

\author{
Jana Gálová
}

\begin{tabular}{|c|c|}
\hline & A B S T R ACT \\
\hline $\begin{array}{l}\text { Objective: Th } \\
\text { terms of the } \\
\text { expectations } \\
\text { opportunities }\end{array}$ & $\begin{array}{l}\text { ain objective is to present the business environment of Ukraine in } \\
\text { sible association with the EU or joining the Customs Union, with } \\
\text { V4 countries, regarding trade relations, potential business } \\
\text { barriers. }\end{array}$ \\
\hline $\begin{array}{l}\text { Research Des } \\
\text { current trade } \\
\text { some statisti } \\
\text { and deductio }\end{array}$ & $\begin{array}{l}\text { \& Methods: The paper is discussing the opinions of researchers, } \\
\text { dicators, information from managed interviews, completed with } \\
\text { data. Using qualitative methods of analysis, synthesis, comparison } \\
\text { e knowledge is summarized and limitations concluded. }\end{array}$ \\
\hline $\begin{array}{l}\text { Findings: As } \\
\text { trade betwee } \\
\text { common trad }\end{array}$ & $\begin{array}{l}\text { main finding we can conclude the fact that the value of mutual } \\
4 \text { and Ukraine shall continue to grow, with limitation due to the EU } \\
\text { licy and trade barriers. }\end{array}$ \\
\hline $\begin{array}{l}\text { Implications } \\
\text { November } 2 \\
\text { signing it res } \\
\text { of mutual (tr } \\
\text { well as deepe }\end{array}$ & $\begin{array}{l}\text { ecommendations: By signing the Association Agreement in } \\
\text { the EU was to become the main trade partner for Ukraine. Not } \\
\text { in protests and political instability, with difficulties in predictions } \\
\text { relations. Nevertheless, preserving close trade links with Russia as } \\
\text { those with the EU is equally essential for Ukraine. }\end{array}$ \\
\hline $\begin{array}{l}\text { Contribution } \\
\text { cooperation } \\
\text { The emergin } \\
\text { opportunities }\end{array}$ & $\begin{array}{l}\text { lue Added: The paper presents rather a unique topic of the } \\
\text { ssinesses within the Eastern Partnership of the European Union. } \\
\text { arkets of the Eastern European Countries (EECs) offer a lot of } \\
\text { European businesses, especially these from Central Europe. }\end{array}$ \\
\hline Article type: & research paper \\
\hline Keywords: & $\begin{array}{l}\text { Visegrad countries (V4); Ukraine; international business; business; } \\
\text { trade; cooperation }\end{array}$ \\
\hline JEL codes: & F18, F23, F64, M31 \\
\hline
\end{tabular}

\section{Suggested citation:}

Gálová, J., (2013). 'Opportunities for Doing Business with Countries Neighbouring V4 - The Case of Ukraine'. Entrepreneurial Business and Economics Review, 1(1), pp. 77-90. 


\section{INTRODUCTION}

Currently we observe intensive changes in business environment both at regional and worldwide level. The reasons of these changes are political, scientific, technological, economic and educational factors brought by the globalisation process. Globalisation can be seen as an opportunity for economic growth, social development and progress, on the other hand it can be a threat to the current world. It must be considered that both possibilities are well founded. The close geographical connection among countries in Central and Eastern Europe gives opportunities for regional cooperation and for the establishment of international relations. Similarities due to common historical, political and cultural background form the first supposition for better understanding of intercultural differences and business distance, and consequently contribute to further trade development. The main objective of the paper is to present viewpoint on the business environment of Ukraine in terms of the possible association with the European Union and connection with the Russian Federation: what are the expectations and what could it bring for the Visegrad (V4) countries, especially for the Slovak Republic, regarding trade relations and potential business opportunities limited by the continuously changing conditions due to political instability from November 2013.

\section{LITERATURE REVIEW}

When choosing a foreign market in the process of internationalization, for most companies the first step tends to be activity towards neighbouring countries when an enterprise initially expands its activities to neighbouring countries with similar cultural, ethnic and consumer conditions and background, states Ubrežiová (2008). From the beginning of doing business on the foreign market the company has to analyse the compatibility of its activities with the interests of the particular country, add Gálová \& Horská (2013). Paluchová \& Benda Prokeinová (2013) continue that decision-making about doing business on a foreign market starts with analysis of the internationalization potential of the company which is followed by a detailed analysis of the foreign market, and the final selection of methods and forms of entry. Different forms of entry on foreign markets are characterized by different efficiency, but also different costs of entry. Wach (2011) highlights the fact that the choice of internationalization methods depends on many objective endogenous as well as exogenous factors which define the given target market. Among internal (corporate) factors Horská (2007) includes company behaviour and activities, the contribution of the company to the development of the national economy, use of local resources, and dependence on the parent company. On the other hand, external factors are the home country of the company, characteristics of the product or industry, size and location of facilities, degree of visibility on the market, and political situation in the country of operation (Horská, 2008).

We should not forget that, particularly in the past several years, according to Kotabe \& Helsen (2010), many political and economic events have affected the nature of global competition. The demise of the Soviet Union, the establishment of the EU and the North American Free Trade Agreement, deregulation, and privatization of stateowned industries have also changed the market environments around the world. Furthermore, the emerging markets of Eastern Europe and the rapidly re-emerging 
markets of Southeast Asia also add promise to international businesses. Kleinová \& Ürgeová (2011) continue that marketing in these emerging markets is contextually different from marketing in developed countries. Companies that have succeeded in developed countries may or may not be able to approach those emerging markets the same way if they underestimate the aforementioned factors. As Doole \& Lowe (2008) add, lesser developed countries and emerging markets pose particularly high political risks, even when they are following reforms to solve the political problems they have. This risk comes from the political environment of international marketing and includes any national or international political factor that can affect the organisation's operations or its decision making. Unstable political regimes expose foreign businesses to a variety of risks that they would generally not face in the home market. This often means that the political arena is the most volatile area of international marketing. Horská, Nagyová \& Felixová (2010) emphasize that due to the unstable political situation in many parts of the world it is essential to continuously monitor the environment, analyze the situation, and try to estimate the degree of possible political risk (i.e. the extent of possible political changes) in a particular situation.

We can agree with Wach (2012) that the enlargement of the European Union (EU) in 2004 with Central and Eastern European countries, but also in 2007 with East-South European Countries, has become a strong impulse to intensify competition in all business areas and led to changes in relationships between the EU and Ukraine. The EU has enlarged to 27 member states, with Poland, Slovakia, Hungary and Romania all directly bordering Ukraine, states Zhemoyda (2008). We also share the opinion of Szmagalska-Follis (2008) that today the boundary line on the Eastern side of the enlarged European Union remains a key site in the geopolitics of Europe, when this area represents the sense of being closer to Europe for Ukraine but at the same time a real border by EU itself. Ukraine with its 604.000 square kilometres, 46 millions of people, some of the best soil in the world and a cheap but generally well-educated labour force is simply too big to ignore.

In the last five years, Ukraine's future was discussed as a choice between three possible ways: direction towards the expanded EU signing the Association Agreement, returning back to the group of post-Soviet countries next to Russia in a Customs Union or staying aside in the gray (neutral) zone. The third option was immediately rejected, but discussions remained regarding the first and second possibility.

Szmagalska-Follis (2008) carried out a research among people in Ukraine in 2007 about their attitude towards the country's further orientation. The author states that the political uncertainty still persisted when shortly after EU enlargement in 2004 the Orange Revolution came in Ukraine. The vast majority of the country's voting population in the western part passionately supported the pro-EU candidate $V$. Yushchenko against V. Yanukovich who represented closer ties with Russia, more favoured in the East. However, there was the third group of people - placing themselves outside of these two parties where both were seen as a renewed dependence. Wira (2012) confirms that at the outbreak of the Orange Revolution Ukrainians strived democratic change and willingness to integrate with Western organization. This preference towards West remained in the business community, my experience from visiting Ukrainian companies in September 2013 showed the same 
opinions, businesses were looking forward to opportunities given by the association to the EU, but at the same time aware of the difficult adaptation to new high standards.

Ukraine has chosen European integration as its strategic priority and was aiming to create preconditions to meet requirements enabling joining the EU. The country's accession to the WTO in 2008 meant the liberalization of the trade regime between Ukraine and the EU - at the same time it was a small step towards the associate membership. Astrov (2013) viewed Ukraine's membership in a Customs Union (CU) with Russia, Belarus and Kazakhstan as rather unlikely because of the WTO membership. The reason is that if Ukraine would raise its customs duties for imports from third countries to the current CU level, these (mostly WTO members) would surely demand compensations. Of course, this problem would not arise if the import tariffs of the CU were adjusted to the Ukrainian level but this is highly unlikely to happen. Under the current circumstances, a full membership of Ukraine in the CU (as suggested by Russia) would be incompatible with its free trade regime with the EU.

On the other hand, a lot of other factors (not only economic, but also demographic) prevent Ukraine's accession to the EU - it lags behind in the development of science and engineering, industry, main social indicators and with its numerous population it cannot be so rapidly integrated into the EU as small Central European countries.

In 2011, negotiations between Ukraine and the EU about the Association Agreement (AA) were concluded. As a part of it the agreement about the Deep and Comprehensive Free Trade Area (DCFTA) has been prepared. DCFTA would offer Ukraine a framework for modernising its trade relations and for economic development by opening markets via progressive removal of customs tariffs and quotas, and by an extensive harmonisation of laws, norms and regulations in various trade-related sectors, creating the conditions for aligning key sectors of the Ukrainian economy to EU standards (European Commission, 2013). However, it is pending signature from 2013 because meanwhile Russia has made attempts to discourage Ukraine from the association and offered to join the newly formed trilateral Customs Union instead. And Ukraine continues to seek the appropriate way of cooperation with the CU.

On August 27, 2012 Ukraine signed a memorandum of cooperation with the Eurasian Economic Commission. During the meeting of the Commonwealth of Independent States (CIS) Council of Heads of State in Minsk, Russian President V. Putin said that in case of signing the AA between the EU and Ukraine it will be impossible for Ukraine to join the CU of the Russian Federation, Belarus and Kazakhstan. He also expressed concern about the impact of the signature on the trade between Russia and Ukraine. Ukraine's president $\mathrm{V}$. Yanukovich responded that the signature will not be a threat and proposed the creation of a joint Consultative Committee of the EU, Russia and Ukraine to clarify relevant issues.

Zhemoyda already in 2008 stated that Ukraine's orientation towards the EU accession prevents to develop international relations within the framework of the CIS (mainly with Russia) and that it is quite evident that it is impossible at the same time to be both in economic union with Russia (or in Eurasian Economic Community) and in the EU.

As opposite, Astrov (2013, p. 34) comes up with an interesting scenario where he focuses on the fact that under the current circumstances Ukraine's membership in a 
free trade area with the EU and in a Customs Union with Russia appears to be mutually exclusive, but this does not need to be the case forever. Clearly, closer trade integration between Russia and the EU would relieve Ukraine from having to make a difficult choice with respect to the direction of integration. For instance, should Russia and the EU enter a free trade agreement, the possibility of which is envisaged in the current EU-Russia Partnership and Cooperation Agreement (PCA), Ukraine's participation in both DCFTA and CU could become perfectly feasible in the longer run. However, for that to become possible, a number of difficult problems - including those of political nature - would have to be solved.

Ukraine has to choose its path alone, but it is just natural that the Visegrad countries are interested in Ukraine's successful European integration, with preference of signing the AA. The first attempt in Vilnius in November 2013 failed which caused unexpected range of protests throughout the country and the situation now is an example of political uncertainty and instability. We now take a look at the business relations between Ukraine and the Visegrad countries and how they would be affected by predicted further development.

\section{MATERIAL AND METHODS}

The methodology of the paper is based on discussing and comparing the opinions and studies of various researchers about the business environment of Ukraine from the perspective of its relations with Visegrad (V4) countries, with the aim of evaluating the current trade relations and predicting further development in terms of signing the Association Agreement with the European Union or joining the Customs Union with the Russian Federation. The paper contains own primary information from managed interviews with business representatives and experience from the research stay in Kyiv during September 2013. This is completed with data gathered from external sources such as scientific literature of well-known authors from the field, specialized online publications and statistical data about mutual trade development among V4 countries and Ukraine during last five years (2008-2013). These have been gained from the ministries of foreign affairs and statistical offices of these countries (namely Central Statistical Office of Poland, Czech Statistical Office, Hungarian Central Statistical Office and Statistical Office of the Slovak Republic as well as the State Statistics Service of Ukraine) as a base for predicting further trends in trade relations among mentioned countries. Using the qualitative methods of analysis, synthesis, comparison and deduction the knowledge from the field is consequently summarized and it shall be a source of comprehensive information for (mainly) Slovak and V4 companies, interested in entering the emerging market of Ukraine. We conclude with a mention of the study's limitations and suggestions for further research.

\section{RESULTS AND DISCUSSION}

The Visegrad group (also known as V4) is represented by four Central European countries, (the Czech Republic, Hungary, Poland and the Slovak Republic) and exists from 1991. V4 countries are members of the EU from 2004. The main objective of the Group was collaboration with the EU and NATO on the issue of accession to the 
structures of these organizations, to consult, coordinate and support each other's efforts in the international arena, says Wira (2012).

Collaboration between Ukraine and V4 conducts annually in many forms such as intergovernmental contacts, different events in the format "V4 + Ukraine" (in political and security sphere, military, energy, sociocultural, educational and regional). Collaboration is taking place on different levels and different spheres, but internal political problems in Ukraine make it less efficient. Regional and transboundary cooperation takes place in forms of euro regions activity, neighbourhood programmes (European Neighbourhood Policy), activity of international regional organizations and interregional cooperation (agreements on transborder cooperation), such as through the International Visegrad Fund or Visegrad 4 Eastern Partnership Program (V4EaP 2013).

Ukraine and the V4 countries maintain developed trade relations among each other. The Ukrainian market represents considerable potential for companies from all Visegrad countries, its full use depends on the implementation of economic reforms by the Ukrainian government, the pace of standardization of business and investment environment of Ukraine, and the process of European integration which at the moment seems as a distant idea. Ukraine is for the Visegrad group an important and strategic partner also as a supplier of raw materials for further processing. The following Tables 1-4 tell us about the mutual trade among Ukraine and the V4 countries and enable to compare these trade flows during last five years.

Table 1. Mutual trade between Ukraine (UA) and the Czech Republic in the years 2008-2013

\begin{tabular}{|l|r|r|r|r|r|r|}
\hline \multicolumn{1}{|c|}{ Year } & \multicolumn{1}{|c|}{$\mathbf{2 0 0 8}$} & \multicolumn{1}{c|}{$\mathbf{2 0 0 9}$} & \multicolumn{1}{c|}{$\mathbf{2 0 1 0}$} & $\mathbf{2 0 1 1}$ & $\mathbf{2 0 1 2}$ & $\mathbf{1 - 1 1 . 2 0 1 3}$ \\
\hline $\begin{array}{l}\text { Export to UA } \\
\text { (in m EUR) }\end{array}$ & 1009.7 & 541.6 & 708.9 & 989.7 & 1328.8 & 1237.1 \\
\hline $\begin{array}{l}\text { Import from UA } \\
\text { (in m EUR) }\end{array}$ & 775.3 & 421.9 & 824.0 & 1010.5 & 885.9 & 901.6 \\
\hline $\begin{array}{l}\text { Turnover } \\
\text { (in m EUR) }\end{array}$ & 1785.0 & 963.5 & 1532.9 & 2000.2 & 2214.7 & 2138.7 \\
\hline $\begin{array}{l}\text { Balance } \\
\text { (in m EUR) }\end{array}$ & +234.4 & +119.7 & -115.1 & -20.8 & +442.9 & +335.5 \\
\hline
\end{tabular}

Source: own calculations based on data from the Czech Statistical Office 2013 and BusinessInfo.cz 2013

The export of the Czech Republic to Ukraine amounted $1.1 \%$ from the total export flow and $0.8 \%$ from the total import flow of the country in 2012. As seen in Table 1, the trade among these countries is developing, therefore in 2012 Ukraine ranked on the 17th place in exporting countries, but regarding imports it fell from the 20th to the 23rd rank (BusinessInfo.cz 2013). Based on the existing trade relations, perspective areas are e.g. the energetic sector, agricultural and agri-food sector, ecology, machinery, metallurgy and chemical industry. 
Table 2. Mutual trade between Ukraine (UA) and Hungary in the years 2008-2013

\begin{tabular}{|c|c|c|c|c|c|c|}
\hline Year & 2008 & 2009 & 2010 & 2011 & 2012 & 1-11. 2013 \\
\hline $\begin{array}{l}\text { Export to UA } \\
\text { (in HUF) }\end{array}$ & 366829.9 & 250660.8 & 401517.4 & 455992.4 & 514631.8 & \\
\hline $\begin{array}{l}\text { Export to UA } \\
\text { (in } m \text { EUR) }\end{array}$ & . & 806.0 & 1413.3 & 1636.0 & 1772.2 & 1806.4 \\
\hline $\begin{array}{l}\text { Import from UA } \\
\text { (in HUF) }\end{array}$ & 262536.5 & 139713.5 & 182355.6 & 275321.4 & 351994.6 & \\
\hline $\begin{array}{l}\text { Import from UA } \\
\text { (in } m \text { EUR) }\end{array}$ & . & 449.2 & 641.9 & 985.9 & 1219.2 & 1141.3 \\
\hline $\begin{array}{l}\text { Turnover } \\
\text { (in } \mathrm{m} \text { HUF) }\end{array}$ & 629366.4 & 390374.3 & 583873.0 & 731313.8 & 866626.4 & . \\
\hline $\begin{array}{l}\text { Turnover } \\
\text { (in } m \text { EUR) }\end{array}$ & . & 1255.2 & 2055.2 & 2621.9 & 2991.4 & 2947.7 \\
\hline $\begin{array}{l}\text { Balance } \\
\text { (in } \mathrm{m} \text { HUF) }\end{array}$ & 104293.4 & 110947.3 & 219161.8 & 180671.0 & 162637.2 & . \\
\hline $\begin{array}{l}\text { Balance } \\
\text { (in EUR) }\end{array}$ & . & +356.8 & +771.4 & +650.1 & +553.1 & +665.0 \\
\hline
\end{tabular}

Source: own calculations based on data from the Hungarian Central Statistical Office 2013 and KSH ${ }^{1} 2012$ 2013

Difficulties in evaluating the trade relations between Hungary and Ukraine (Table 2) occur as many data are available only in the value of national currency (Hungarian forints - HUF) and due to the exchange rate fluctuations the calculation to Euros is not easy what makes the comparison with other three V4 countries in earlier years difficult. However, data in national currency shows clearly positive development and rise in case of both exports and imports.

Poland is the largest from the V4 countries and has the closest relations with Ukraine. As expected, the export of Poland to Ukraine is the highest among the mentioned countries (Table 3 ) and amounts $2.8 \%$ from the total export flow and $1.1 \%$ from the total import flow of the country as for the period January-November 2013.

Table 3. Mutual trade between Ukraine (UA) and Poland in the years 2008-2013

\begin{tabular}{|l|r|r|r|r|r|r|}
\hline \multicolumn{1}{|c|}{ Year } & \multicolumn{1}{c|}{$\mathbf{2 0 0 8}$} & \multicolumn{1}{c|}{$\mathbf{2 0 0 9}$} & \multicolumn{1}{c|}{$\mathbf{2 0 1 0}$} & \multicolumn{1}{c|}{$\mathbf{2 0 1 1}$} & $\mathbf{2 0 1 2}$ & $\mathbf{1 - 1 1 . 2 0 1 3}$ \\
\hline $\begin{array}{l}\text { Export to UA } \\
\text { (in m EUR) }\end{array}$ & 4345.3 & 2462.7 & 2979.9 & 3377.2 & 4096.9 & 3178.3 \\
\hline $\begin{array}{l}\text { Import from UA } \\
\text { (in m EUR) }\end{array}$ & 1583.4 & 817.4 & 1384.4 & 2011.8 & 1978.9 & 1199.1 \\
\hline $\begin{array}{l}\text { Turnover } \\
\text { (in m EUR) }\end{array}$ & 5928.7 & 3280.1 & 4364.3 & 5389.0 & 6075.8 & 4377.4 \\
\hline $\begin{array}{l}\text { Balance } \\
\text { (in m EUR) }\end{array}$ & +2761.9 & +1645.3 & +1595.5 & +1365.4 & +2118.0 & +1979.2 \\
\hline
\end{tabular}

Source: own calculations based on data from the Central Statistical Office 2008-2013

The export of Slovakia to Ukraine amounted $0.7 \%$ from the total export flow and $1.0 \%$ from the total import flow of the country in 2012 when total exports decreased by $6.7 \%$ compared to 2011, but it seems they grew again in 2013. Ukraine in 2012 imported goods to Slovakia worth 593.3 m EUR (Table 4) which means a decrease of $2.4 \%$ compared to 2011 . 
Table 4. Mutual trade between Ukraine (UA) and Slovakia in the years 2008-2013

\begin{tabular}{|l|r|r|r|r|r|r|}
\hline \multicolumn{1}{|c|}{ Year } & \multicolumn{1}{c|}{$\mathbf{2 0 0 8}$} & \multicolumn{1}{c|}{$\mathbf{2 0 0 9}$} & \multicolumn{1}{c|}{$\mathbf{2 0 1 0}$} & $\mathbf{2 0 1 1}$ & $\mathbf{2 0 1 2}$ & $\mathbf{1 . - 1 1 . 2 0 1 3}$ \\
\hline $\begin{array}{l}\text { Export to UA } \\
\text { (in m EUR) }\end{array}$ & 504.7 & 252.3 & 368.9 & 472.0 & 442.1 & 439.5 \\
\hline $\begin{array}{l}\text { Import from UA } \\
\text { (in m EUR) }\end{array}$ & 665.9 & 291.8 & 446.7 & 607.8 & 593.3 & 577.9 \\
\hline $\begin{array}{l}\text { Turnover } \\
\text { (in m EUR) }\end{array}$ & 1170.6 & 544.0 & 815.6 & 1079.8 & 1035.4 & 1017.4 \\
\hline $\begin{array}{l}\text { Balance } \\
\text { (in m EUR) }\end{array}$ & +161.2 & +39.5 & -77.8 & -135.8 & -151.2 & -138.4 \\
\hline
\end{tabular}

Source: own calculations based on data from the Statistical Office of the SR 2013 and MZV 2013

Now we take a look at the commodity structure of foreign trade among these two countries. The main items of Slovak export to Ukraine in 2012 were road vehicles worth $62.8 \mathrm{~m}$ EUR ( $14.2 \%$ of the total export of the SR to Ukraine), iron and steel worth 52.5 $m$ EUR (11.9\%), equipment for telecommunications, sound recording and reproducing valued at $51.4 \mathrm{~m}$ EUR (11.6\%), nuclear reactors, boilers, machinery worth $54.2 \mathrm{~m}$ EUR (12.3\%), plastics worth $37.8 \mathrm{~m}$ EUR (8.6\%), paper, paperboard and articles thereof worth $23.6 \mathrm{~m}$ EUR $(5.3 \%)$ and others. The main items of import to Slovakia from Ukraine were iron ore and metal scrap worth $308.0 \mathrm{~m}$ EUR $(51.8 \%$ share of total imports), natural gas $47.8 \mathrm{~m}$ EUR (8.1\%), means for distributing electric energy $45.3 \mathrm{~m}$ EUR (7.6 \%), iron and steel worth $42.3 \mathrm{~m}$ EUR (7.1\%), coal 40,4 m EUR (6.8 \%), garment products worth $10.8 \mathrm{~m}$ EUR (1.8\%), veneer, plywood, particle board in the amount of $9.2 \mathrm{~m}$ EUR (1.6 \%) and others (MZV 2013). Slovakia registered negative balance of mutual foreign trade with Ukraine for 2012 in the amount of $151.2 \mathrm{~m}$ EUR, compared with the same period in 2011 higher by $11.8 \%$.

Slovak export to Ukraine for the period from January to November 2013 reached $439.5 \mathrm{~m}$ EUR according to the Statistical Office of the Slovak Republic (2013) while Slovak import from Ukraine for the same period reached $577.9 \mathrm{~m}$ EUR. This leads us to the conclusion that fourth year in row Slovakia has negative balance of mutual foreign trade with Ukraine, given the import of raw materials needed for manufacturing and energetic sector of the Slovak Republic as well as the import of products for distribution in the EU market.

To summarize this part, an essential feature of the mutual trade of Ukraine and V4 countries is the ability of these countries to continuously increase the value of mutual trade. The growth of mutual trade has a similar rate as that of every analysed country's total trade and this growth will continue (as will grow the growth rate of the economy, estimated e.g. by Peng 2014). As a result, each country has a constant position in each other's territorial trade structure and therefore there is still interest to develop and improve mutual trade relations. In addition, we must agree with Svatoš \& Smutka (2008) as they state that Ukraine is a traditional trade partner of all the Visegrad group members. Three of them share a common border together with Ukraine (the Slovak Republic, Hungary and Poland) and the last one, the Czech Republic, also maintains very good relationship with this post-Soviet country. However, in spite the fact that the Ukrainian share in the total value of mutual trade is stable, the values of exports and imports are not adequate for a country with 46 million people. On the other hand, it 
must be emphasised that mutual trade between the V4 countries and Ukraine is limited by the EU common trade policy and EU trade tariff and non-tariff barriers.

Nevertheless, it is still necessary to explain the reasons of differences among the above mentioned countries regarding trade relations with Ukraine. The difference is especially in the size of economies and different size of markets. Whilst the Czech and Slovak Republics and Hungary are small countries with highly concentrated manufacturing industries (where considerable part of the production is produced by foreign owners to be exported) with population of 26 million consumers together, Ukraine and Poland are in a different situation. Their markets are bigger ( 85 million consumers) and also the concentration of the manufacturing industry is not as high, therefore the high amount of production is produced for their domestic markets and not for exports. Other reasons include the localisation of individual countries within the framework of Europe and of the EU, with different current political, economic, social and legal frameworks in every analysed country.

Regarding the territorial division of Ukraine, its economic potential focuses on six regions: Kiev, Doneck region, Dniepropietrowsk region, and regions luganski, charkowski and zaporowski, with $60 \%$ of the industrial production and concentrating investments and creates opportunities for the country's development as well as becomes a determinant of the socioeconomic development (Susfal 2012). Appearing differences among the regions' structure, which result from historical and geographical conditions, caused that individual regions of Ukraine were assigned to three groups: eastern (most industrialized, with deposits of raw materials), central (with the capital Kyiv, mainly farming) and western (industrial and agricultural production, but low level of the cropland, future focus on the sphere of services).

According to the data from the report of PwC (2013), Ukraine's main export products are metals and agriculture products (together accounting for $40 \%$ of exports). The main items imported are mineral fuel, petroleum and petroleum distillation products, machines with equipment and chemicals. CIS and European countries account for more than $70 \%$ of Ukraine's foreign trade. In recent years, the export of Ukraine to Europe and CIS is approximately on the same level (about $35 \%$ ), but speaking about import nearly $45 \%$ goes to CIS (mainly Russia) and just $38 \%$ to Europe (mainly EU). Regarding export to CIS, to Russia the share is about 25 \% (Astrov 2013) and probably more importantly, Russia is the principal export market for Ukraine's more sophisticated products such as machinery and equipment, thanks to the technological links inherited from the Soviet times. In contrast, Ukraine's exports to the EU are heavily concentrated on raw materials and manufactured goods with low valueadded, such as basic metals and fertilizers.

The prerequisites for doing business in Ukraine include the market size, geographical proximity, competitiveness of goods and services, common border (all Visegrad countries except the Czech Republic), still relatively unsaturated market, many similarities between the language and mentality (all Visegrad countries except Hungary), and the implementation of economic reforms. Until November 2013, the real prospect of European integration was considered among the reasons in favour of doing business here.

The disadvantages of doing business in Ukraine include the concentration of state and public authority, possible corruption especially in state and municipal entities, the 
complexity of the administrative procedures of doing business, and the shadow economy.

Škurla as the representative of the General Consulate of the Slovak Republic in Uzhgorod and Krajčová from the Embassy of the Slovak Republic in Ukraine, Kiev processed economic information about the territory of Ukraine in 2013. They give advice Slovak companies regarding the entry to the Ukrainian market. First of all, if the company wants to successfully penetrate the market, it should conclude a strategic decision to process opportunities for doing business on this perspective market. Here, great asset is the linguistic and professional preparedness of responsible staff, with the opportunity to complete a series of personal discussions in Ukraine. Patience is needed in trade negotiations whereas no initial failures should discourage firms from Slovakia from their strategic plan to enter the Ukrainian market (Škurla \& Krajčová 2013).

As in any other foreign market, it is necessary first to gather basic information about the market and to carry out marketing research in relation to the selected product which the particular company wants to export, including a review of regulatory measures, customs formalities, domestic producers, market potential, size, diversity and target groups. Useful is visiting specialized trade fairs and exhibitions where it is possible to meet potential customers, but also future competitors and to get to know potential competition.

Marketing strategy when exporting to the territory is closely linked with trade practices in the territory. One of the most important aspects of successful business in Ukraine is finding a reputable and reliable Ukrainian partner. Experience shows that without the use of local representative it is very difficult to penetrate the market of Ukraine. It is essential to realize that Ukraine is a country with a high concentration of state power, complex administrative procedures (which are slowly simplifying), and decision-making processes largely based on personal relationships. In this sense, a reliable local business partner with good links to local government and local authorities is a huge benefit. Finding a reliable partner in Ukraine is usually the result of concentrated efforts after negotiations with several potential partners in order to reach the right decision. In any case, it is desirable to somehow verify the seriousness of the Ukrainian partner, his financial and economic stability and references. It is therefore highly recommended to have direct personal contact with potential business partner in Ukraine, rather than sending written materials, or promotion information by post or email. Of course, such forms can be used for communication, but the result and efficiency is questionable in the early stage of business relations.

Foreign firms are operating in the territory in the form of joint stock companies, limited liability companies and foreign representations. In some cases it may be an advantage to set up a subsidiary in Ukraine, e.g. in order to build a distribution warehouse, to participate in electronic auctions or in public procurement of state and municipal entities in the country.

Regarding the foreign direct investment saturation Ukraine still lags far behind the developed countries of the world, therefore, it offers plenty of scope for the implementation of investment projects. If a company is interested in investing in Ukraine, it needs to carefully consider the potential risks and guarantee options given the current state of the investment climate in Ukraine. Analysis of potential risks needs attention especially during early stages in the decision-making process. Thorough 
calculation and knowledge of market, competition, but also own business and financial opportunities are essential part of this process. Certainly, as with all trade and business activities, it is necessary to consider the business risk and consequently the willingness to bear the loss in case of failure.

One of the most promising sectors for investment in Ukraine is agriculture and animal production. The farming sector of Ukraine gained the status of the leading sectors of Ukrainian economy over the last two years. Perspective areas of investment in Ukraine are also constructing urban infrastructure, streamlining municipal economy and increasing energy efficiency of Ukrainian industrial and agricultural enterprises (Škurla \& Krajčová, 2013).

Given the needs of the Ukrainian economy, promising sectors and possibilities of cooperation between Slovakia and Ukraine are: modernization of the production base (new technologies in housing and municipal services, heat and water supply, energy conservation, waste recycling), energetics, transport infrastructure, agricultural and agri-food complex, the field of ecology, engineering, metallurgy, chemical industry, tourism and services.

On the other hand, we should not forget that Ukraine still has a high degree of bureaucracy and corruption. This is certainly reflected in the business field, in the registration process, communication and handling of various endorsements and statements. In the field of justice, the priority of rights is still at a low level, let alone assessing the lawsuit of a foreign company against the domestic entity. Currently, in both sectors the government promises changes, but the current situation is still nontransparent and challenging with many difficulties. The specifics of doing business in Ukraine further include challenges in legislation when it is just slowly adapting to standard international conditions and there are large gaps within the legal and institutional framework. In addition, common breach of negotiated contracts and the low purchasing power of the population (where the middle class is small in quantity and weak) also can discourage foreign companies.

To sum up, major problems of the Ukrainian market remain the high level of corruption, uncertainty about the political situation and the ability to ensure the stability of doing business, state intervention in the economy, asserting the interests of monopoly structures linked to the government, unresolved privatization of enterprises, insufficient protection of intellectual property rights, high level of bureaucracy, barriers to import and certification, imperfect executive legislation, and the related complex law enforcement.

\section{CONCLUSIONS}

The dynamism of Central and Eastern European countries economic development enables us to state that without any doubts this territory and these countries are continuously improving their position within the scope of the globalisation process and mutual relations.

We were expecting the signing the Association Agreement by Ukraine in November 2013 in Vilnius and consequently the EU to become the most important market for Ukrainian goods and the main trade partner for Ukraine. At least, the information from Ukrainian companies said so. However, not signing the mentioned 
agreement caused an unprecedented range of protests throughout Ukraine and the current political development makes it incredibly difficult to come up with exact predictions of mutual (trade) relations.

The topic's limitation therefore lies in the daily changing situation in Ukraine, on the other hand, it enables future research about how is the current instability going to influence the growing trade indicators and the willingness of foreign companies to invest in this country. V4 countries were always focusing on maintaining good relations with Ukraine and we cannot predict what kind of impact will have this uncertainty on trade balance.

We should not forget that preserving close trade links with Russia (as well as deepening those with the EU) is essential for Ukraine. It would ensure the best solution for Ukraine not only in economic, but also in political terms, as it would reduce incentives for the geopolitical competition between Russia and the EU on the postSoviet space.

\section{REFERENCES}

Astrov, V 2013, 'The EU and Russia: Both Important for Ukraine', in Ukraine at Crossroads: Prospects of Ukraine's Relations with the European Union and Hungary: materials of the International Conference "Where Is Ukraine Headed in the Wake of the 2012 Parliamentary Elections?" (November, 14, 2012, Budapest), eds P Balázs, S Myryayeva \& B Zákonyi, Lira, Budapest - Uzhorod, pp. 32-37.

BusinessInfo.cz 2013, Souhrnná teritoriální informace Ukrajina, Available from: <http://www.businessinfo.cz/cs/zahranicni-obchod-eu/teritorialni-informacezeme/ukrajina.html> [24 December 2013].

Central Statistical Office 2009, Foreign Trade January-December 2008, Available from: <http://www.stat.gov.pl/cps/rde/xbcr/gus/pt_foreign_trade_01-12_2008.pdf> December 2013].

Central Statistical Office 2010, Foreign Trade, Available from: <http://www.stat. gov.pl/cps/rde/xbcr/gus/pt_foreign_trade_01-12_2009.pdf> [24 December 2013].

Central Statistical Office 2013, Foreign Trade January - December 2012, Warszawa, Available from: $\quad$ http://www.stat.gov.pl/cps/rde/xbcr/gus/PT_foreign_trade_2012.pdf> Decemebr 2013].

Central Statistical Office 2014, Yearbook of Foreign Trade Statistics of Poland 2013, Available from: <http://www.stat.gov.pl/cps/rde/xbcr/gus/SY_yearbook_of_foreign _trade_statistics_2013.pdf> [24 January 2014].

Czech Statistical Office (Český Statistcký Úřad) 2013, Foreign Trade Statistics, Available from: <http://apl.czso.cz/pll/stazo/STAZO.STAZO> [24 December 2013].

Doole, I \& Lowe, R 2008, International Marketing Strategy: Analysis, Development and Implementation, 5th ed, Cengage Learning EMEA, London.

European Commission 2013, EU - Ukraine Deep and Comprehensive Free Trade Area, Available from: <http://trade.ec.europa.eu/doclib/docs/2013/april/tradoc_150981.pdf> December 2013].

Gálová J \& Horská E 2013, 'Sustainability in Business: Global Challenges in International Business'. In HORSKÁ, E. et al., Sustainability in business and society: global challenges - local solutions, Wydawnictwo Episteme, Kraków. 
Horská E, Nagyová L' \& Felixová I 2010, 'CAGE distance framework among Visegrad countries, Ukraine and Russia and lessons for international business', in Economics, Social Policy and Citizenship in the European Union : Evidence of V4 Countries and Perspectives for Ukraine, eds P Bielik et al., SUA, Nitra, pp. 54-98.

Horská, E 2007, Medzinárodný marketing, SPU, Nitra.

Horská, E 2008, 'Medzinárodný marketingový program a ciel'ové trhy', in Internacionalizácia agropotravinárskych podnikov SR, eds E. Horská et al., SPU, Nitra, pp. 199-234.

Hungarian Central Statistical Office (Központi Statisztikai Hivatal) 2013, Foreign Trade Statistics, Available from: <http://www.ksh.hu/externaltrade_statistics> [24 December 2013].

Kleinová, K \& Ürgeová, J 2011, 'Country image and branding of Slovakia', Polityki europejskie, vol. 54 , no. 5 , pp. 50-58.

Kotabe, M \& Helsen, K 2010, Global marketing management, 5th ed, Wiley, Hoboken NJ.

KSH 2012, External Trade by Main Partner Countries, Available from: <http://www.ksh.hu/docs/hun/xttp/gyor/kul/kul31112.pdf> [24 December 2013]

KSH 2013, A külkereskedelmi termékforgalom forintban, országok szerint (2001-), Available from: <http://www.ksh.hu/docs/hun/xstadat/xstadat_eves/i_qkt009b.html?2600> [24 December 2013].

KSH 2013, External trade in goods, January - November 2013, Statistical Reflections, Vol. 8, No. 5, Available from: <http://www.ksh.hu/docs/eng/xftp/gyor/kul/ekul21311.pdf> [24 December 2013].

MZV 2013, Zahraničný obchod - Celkový dovoz a celkový vývoz SR podl'a mesiacov, Ministry of Foreign and European Affairs of the SR, Available from: <http://www.mzv. sk/App/wcm/media.nsf/vw_ByID/ID_BD88A89EE2FCFFD3C1257A44004D64B2_SK/\$File/Cel kov\%C3\%BD\%20dovoz\%20a\%20celkov\%C3\%BD\%20v\%C3\%BDvoz\%20Slovenskej\%20republi ky\%20pod\%C4\%BEa\%20mesiacov.pdf> [22 December 2013].

Paluchová J \& Benda Prokeinová R 2013, Udržatel'né tendencie v spotrebitel'skom správaní: Asociačné pravidlá, udržatel'ný marketing a zodpovedná spotreba, Nitra.

Peng, M 2014, Global Business, 3rd ed., South-Western Cengage Learning, Mason.

PwC 2013, Doing business and investing in Ukraine, PricewaterhouseCoopers, Available from: <http://www.pwc.com/en_UA/ua/survey/2013/assets/ukraine_doingbusiness_2013. pdf $>$. [22 December 2013].

Škurla, A \& Krajčová, S 2013, Ekonomická informácia o teritóriu - Ukrajina, Ministerstvo zahraničných vecí a európskych záležitostí SR, Generálny konzulát SR v Užhorode, Velvyslanectvo SR na Ukrajine, Kyjev.

Statistical Office of the Slovak Republic 2013, Foreign Trade, Available from: <http://slovak.statistics.sk> [22 December 2013]

Susfal, BP 2012, 'Economic Transformation of Ukraine', Zbirnik tez dopovidejj Mizhnarodnogo studentskogo forumu «Model kraï Vishegradskoï chetvirki $v$ integraciï molodi $v$ edinijj naukovo-kulturnijj prostir», BIEM, Luck, pp. 116-118.

Svatoš, M \& Smutka, L' 2008, 'The Analysis of External Trade Development among the Czech and Slovak Republics, Hungary, Poland and the Ukraine (V4+1)', in Agricultural market and trade: evidence and perspective of V4 region and its neighbour - Ukraine : Visegrad Fund, eds P Bielik, B Klepacki \& S Kvasha, Wieś Jutra, Warszawa, pp. 119-151.

Szmagalska-Follis, K 2008, 'Repossession: Notes on Restoration and Redemption in Ukraine's Western Borderland', Cultural Anthropology, vol. 23, no. 2, pp. 329-360.

Ubrežiová, I 2008, Medzinárodný manažment a podnikanie, SPU, Nitra. 
V4EaP 2013, Visegrad 4 Eastern Partnership Program (V4EaP), Available from: <http://visegradfund.org/v4eap/> [11 December 2013]

Wach, K 2011, 'Managing International Business: Case of Poland' in European Studies on Intercultural Dimension of International Business: Marketing and Managerial Consequences, ed E Horská et al., Slovak University of Agriculture, Nitra, pp. 81-94.

Wach, K 2012, 'Internationalization Strategies for SMEs' in Internationalization of SMEs: Context, Models and Implementation, eds $\mathrm{N}$ Daszkiewicz \& $\mathrm{K}$ Wach, Gdansk University of Technology, Gdansk, pp. 40-62.

Wira, K 2012, 'The Visegrad Group and the Eastern Partnership in Support of Ukraine's Relations with the European Union', Zbirnik tez dopovidejj Mizhnarodnogo studentskogo forumu "Model kraïn Vishegradskoï chetvirki v integraciï molodi v $\epsilon$ dinijj naukovo-kulturnijj prostir», Luck: BIEM. s. 26-28.

Zhemoyda, O 2008, 'Regional Development of Rural Areas in Ukraine and Other Central and Eastern Europe Countries', in Agricultural market and trade: evidence and perspective of V4 region and its neighbour - Ukraine : Visegrad Fund, eds P Bielik, B Klepacki \& S Kvasha, Wieś Jutra, Warszawa, pp. 90-104.

\section{Author}

\section{Jana Gálová}

PhD Student and assistant lecturer at the Faculty of Economics and Management of Slovak University of Agriculture in Nitra (Slovakia). A project manager of the mobility network CEEPUS entitled 'Applied Economics and Management' based on a consortium of 19 Central European universities. Bachelor degree in Business Management and Master degree in Trade and Marketing from Slovak University of Agriculture in Nitra (Slovakia).

\section{Correspondence to:}

Ing. Jana Gálová (PhD Student)

Slovak University of Agriculture in Nitra

Faculty of Economics and Management

Department of Marketing

Tr. A. Hlinku 2, 94976 Nitra, Slovakia

xgalovaj@is.uniag.sk

Published by Centre for Strategic and International Entrepreneurship - Krakow, Poland 